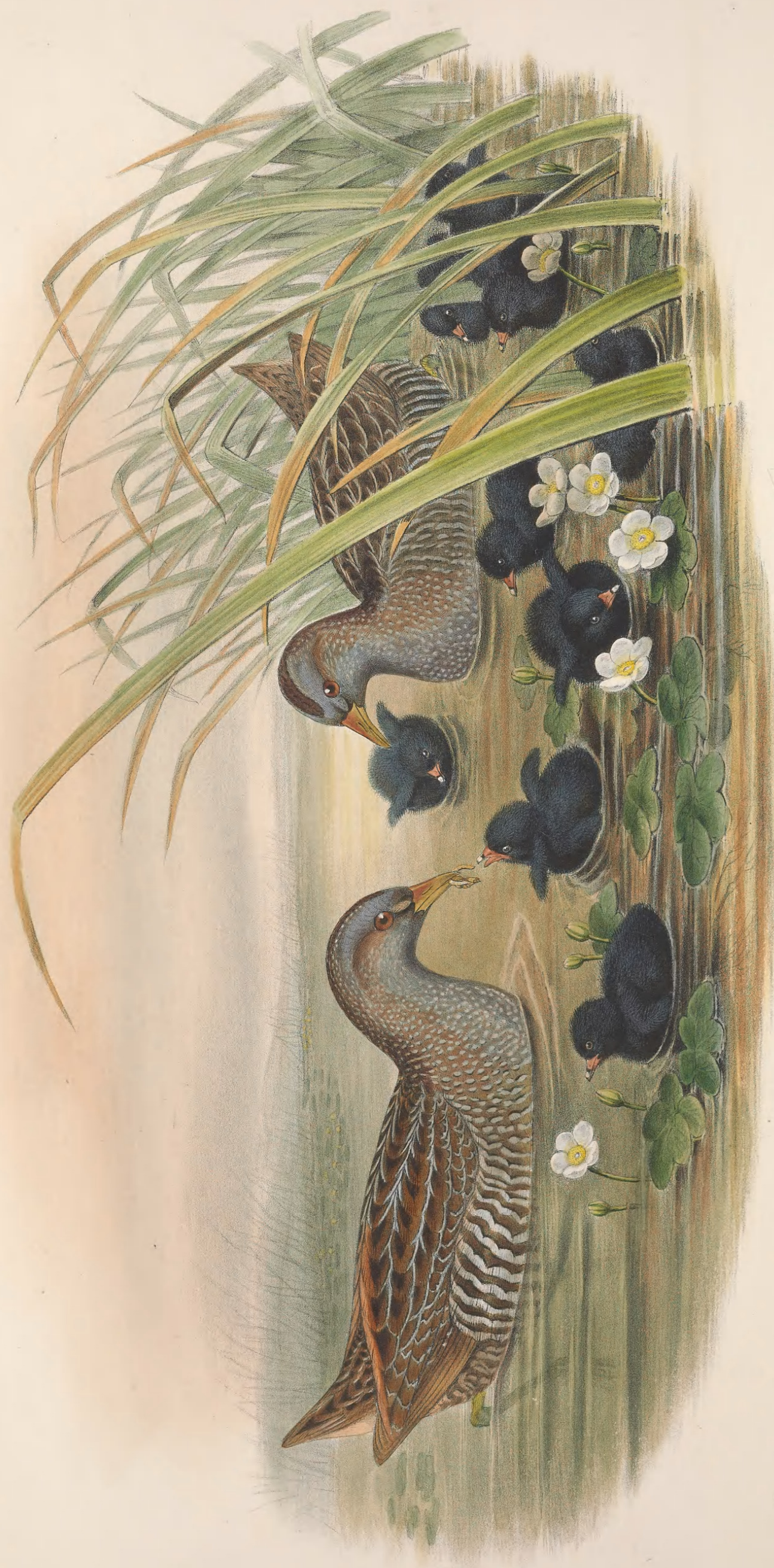

年) 


\title{
PORZANA MARUETTA.
}

\author{
Spotted Crake.
}

Rallus Porzana, Linn. Syst. Nat., tom. i. p. 262.

aquaticus minor sive maruetta, Briss. Orn., tom. v. p. 155, pl. 13 fig. 1 .

Gallinula porzana, Lath. Ind. Orn., vol. ii. p. 772.

, maculata, et punctata, Brehm, Handb. der Naturg. Vög. Deutschl., pp. 696, 698, 699.

Porzana maruetta, Vieill.

Zapornia porzana, Gould, Birds of Europe, vol. ix. pl. 343

Crex porzana, Selby, Ill. Brit. Orn., vol. ii. p. 179.

Ortygometra porzana, Steph. Cont. of Shaw's Gen. Zool., vol. xii. p. 223.

THE Spotted Crake is the largest as well as the most prettily marked species of the small but well-defined genus of birds to which the generic name of Porzana has been assigned. In this country it is principally a summer visitant, arriving in March and April, and departing again in September or October. Its dispersion over England, Ireland, and Scotland is very general; but it is much less numerous in the two latter countries than in the former. In structure it is very similar to the Land-Rail, and it also assimilates very closely to that species in its skulking habits and general mode of life. It affects sloppy marshy districts rather than open grassy fields, and is altogether more aquatic than its ally; hence the fenny districts of Lincolnshire, Norfolk, Suffolk, and Huntingdonshire are the situations where it is most frequently found; but that it does occasionally occur elsewhere is proved by the fact that examples have been killed in every county, from Cornwall to the most northern parts of England. In a word, it may be found wherever there are rivers and large ponds with sedgy banks, and in all swampy depressions. In such situations it constructs its nest, and nurtures its silken-black young in safety; for the nest, being always placed in the thickest parts of the reeds and tangled herbage, is most difficult of detection. By far the best account of this part of the bird's economy I have yet seen is contained in Mr. Hewitson's work 'On the Eggs of British Birds,' and this I shall take the liberty of transcribing :-

"Mr. J. Hancock has a beautiful series of the eggs of this species, obtained by him during a bird-nesting excursion through the fenny districts of the counties of Cambridge and Huntingdon-some collected on the borders of Whittlesea Mere, but chiefly in Yaxley Fen; to him I am indebted for the following information :The eggs of the Spotted Crake, as well as those of the Water-Rail, which are met with in exactly similar situations, are in ordinary seasons very difficult to obtain, the nest being placed in a thick bed of reeds, which covers a large extent of country, growing to a height of six or seven feet, and therefore not easily penetrated. It happened that the year had been unusually wet, and that the fen-country had been covered with water, so that both these species, which had had their nests swamped, and their eggs and young ones destroyed during the usual breeding-season in the beginning of May, were a second time engaged in incubation at the time of my visit in July, which was also the season during which the fenmen were mowing the reeds, and uncovering the nests of these two species, in the same way that those of the Corn-Crake are exposed by cutting down the long grass. Several of the nests of the Spotted Crake, which were not so numerous as those of the Water-Rail, were thus readily obtained. They were placed on the marshy ground, on a bed of broken reeds, and were formed of the long ribbon-like grass of the reeds, and lined with a finer soft grass, which distinguishes them from those of the allied species. They contained from seven to ten eggs each, varying considerably, but always characteristic of the species." The eggs are represented in Mr. Hewitson's plate of a buffy stone-colour, blotched all over with irregular patches of reddish brown, some of which are darker and larger than others.

With respect to the distribution of this bird in other counties besides those above mentioned, I find, in the 'Zoologist' for March 1864, a notice from the pen of Mr. W. W. Boulton, to the effect that during' the year 1863 no less than sixteen individuals were killed or captured alive on the river Hull; and that Mr. Hurd, of Beverley, had certainly shot not less than ten others, and Mr. Holmes and Mr. Simpson, of the same neighbourhood, had killed six more, making a total of thirty-two specimens obtained, besides others that were only seen; all that were procured were used for the table, and proved excellent eating.

The sexes of the Spotted Rail present no very marked difference in their colouring; neither do the young of the year vary materially from the adults after their feathers are sufficiently developed to enable them to perform their autumnal journey across the seas to Spain, Portugal, and Africa-a journey which is undertaken about the time, or perhaps a little later than the departure of the young Land-Rails on a similar errand, that is to say, when nipping frosts forewarn the bird of the approach of winter-a season not congenial to its habits or mode of life. I have always intended that my illustrations of the downy state of 
our native birds should form a conspicuous feature in the present work; and I think that, so far as the marsh-birds are concerned, this intention has been fully carried out in my plates of the Coot, the Moorhen, and the Water-Rail. I have ever regarded these newly hatched creatures with great interest. At first the old birds attend them assiduously in the daytime, and shelter them under their wings during the night; but, from the hour they are hatched, the nestlings are endowed with the requisite power for gaining their own subsistence, and they grow so rapidly that a few days only elapse before the downy covering is thrown off, and stub feathers appear, as shown in my figures of the young Land-Rails. The development of these feathers progresses with rapidity, and nature perfects a structure adapted for performing a distant migration in a surprisingly short space of time. How wonderful is all this! June has probably far advanced before the eight or ten eggs of the Spotted Rail are deposited, and July fairly commenced before their young see the light of day; and yet in two months' time they are performing what we must consider a perilous journey over extensive seas, with instinct alone for a guide as to the route they are to pursue; and thus we see that the little balls of black glistening down, represented in the accompanying Plate, are converted into an aërial form in a few weeks.

The range of the Porzana maruetta is most extensive; for not only is it an iuhabitant of every part of Europe suited to its mode of life, but it is also found over the greater part of Africa, Persia, and India : in most if not all these countries it is a migrant, visiting the temperate and northern ones in summer, and the southern at the opposite season.

The fliglt of the Spotted Crake is of the same heavy and laboured character as that of the Land-Rail. When compelled to take wing, it rises with its legs hanging behind it, and merely passes over the tops of the reeds to some place of security a short distance off. On the other hand, it runs with great celerity, and threads the tangled herbage with the ease and facility shown by the Water-Rail. It swims in like manner; and in case any of my readers should consider that $\mathrm{I}$ am incorrect in figuring the young on the surface of the water, I may mention that, if they do not habitually, they very frequently, take to that element the hour they are excluded from the shell, and, like young Moorhens, run over the floating leaves, and scramble down the fallen rushes, at one moment swimming, at the next catching insects from the surface or the underside of the aquatic plants forming part of the herbage among which they are dwelling. Broods of Spotted Crakes have doubtless been reared in the middle of a marsh, and under these circumstances may not be able to get to the water for some days.

$\mathrm{Mr}$. Selby states that the flesh of the Spotted Crake is sweet and well-flavoured, and that in autumn the bird has a layer of fat, nearly a quarter of an inch in thickness, over the whole surface of the body; and I have myself seen fully fledged young birds so fat, that in hot weather they almost melted in the hand: could they be procured in any number, they would doubtless be much sought after as a bonne bouche for the epicure.

The Plate represents a male and a female, with a brood of young about two days old, of the size of life. The plant is the Ranunculus fuviatilis. I am indebted to Edward Cock, Esq., of Lydd in Kent, for the very fine example from which my principal figure was taken. 


\section{$2 \mathrm{BHL}$ Biodiversity Heritage Library}

Gould, John. 1873. "Spotted Crake, Porzana maruetta [PI. 88]." The birds of Great Britain 4, -. https://doi.org/10.5962/p.324042.

View This Item Online: https://www.biodiversitylibrary.org/item/221609

DOI: https://doi.org/10.5962/p.324042

Permalink: https://www.biodiversitylibrary.org/partpdf/324042

\section{Holding Institution}

Smithsonian Libraries

\section{Sponsored by}

Biodiversity Heritage Library

\section{Copyright \& Reuse}

Copyright Status: Public domain. The BHL considers that this work is no longer under copyright protection.

This document was created from content at the Biodiversity Heritage Library, the world's largest open access digital library for biodiversity literature and archives. Visit BHL at https://www.biodiversitylibrary.org. 